\title{
Fungsi, Bentuk, dan Makna Gerak Tari Jaranan Turonggo Yakso Kecamatan Dhongko Kabupaten Trenggalek
}

\author{
Tri Rusianingsih a, ${ }^{*}$, Yuddan Fijar Sugma Timur b,2 \\ ab Sekolah Tinggi Kesenian Wilwatikta, Jalan Klampis Anom II, Surabaya, 60117, Indonesia \\ ${ }^{1}$ trirusianingsih@yahoo.co.id; ${ }^{2}$ yuddan.kaconk@gmail.com
}

* Corresponding Author

\begin{tabular}{l}
\hline INFO ARTIKEL \\
\hline Sejarah Artikel: \\
Diterima: 12 September \\
2020 \\
Direvisi: 16 Oktober \\
2020 \\
Disetujui: 9 November \\
2020 \\
Tersedia Daring: 16 \\
November 2020 \\
\hline Kata Kunci: \\
Bentuk Penyajian \\
Fungsi Pertunjukan \\
Jaranan Turonggo Yakso \\
Makna Gerak \\
Pertunjukan
\end{tabular}

ABSTRAK

Kehadiran jaranan Turonggo Yakso pada awal-mulanya diinspirasi oleh keberadaan kegiatan upacara adat yang sering disebut dengan baritan. Upacara yang dilakukan masyarakat tersebut merupakan bentuk upacara bersih desa yang bertujuan untuk memohon kepada Hyang Widi (Tuhan Penguasa Alam) dan mensyukuri atas hasil panen, maupun supaya hewan ternak mereka juga dapat dihindarkan dari segala jenis penyakit. Penelitian bertujuan mendeskripsikan fungsi, bentuk penyajian dan makna gerak tari jaranan Turonggo Yakso. Konsep pertunjukan digunakan sebagai alat analisa penelitian. Penelitian menggunakan metode deskriptif-kualitatif. Teknik pengumpulan data dengan observasi, wawancara, studi pustaka serta dokumentasi. Analisis dilakukan dengan deskripsi mendalam. Hasil penelitian menunjukkan terjadi pergeseran fungsi dari fungsi sakral ke profan. Bentuk penyajian terdiri dari gerak baku dan gerak tambahan. Gerakan pertunjukan ini memiliki makna yang berkaitan dengan kegiatan bertani. Gambaran jaranan (turonggo) yang berkepala raksasa (yakso) merupakan simbol dari hawa nafsu yang harus dijinakkan atau ditunggangi agar tidak liar.

Keywords: ABSTRACT

Form of Presentation

The presence of Turonggo Yakso jaranan at first was inspired by the Function of Performance Jaranan Turonggo Yakso Meaning of Motion Performance existence of traditional ceremonies which are often referred to as baritan. The ceremony carried out by the community is a form of village clean ceremony which aims to beg Hyang Widi (God the Ruler of Nature) and be grateful for the harvest, as well as their livestock sheds can al so be protected from all kinds of diseases. This study aims to describe the function, form of presentation and meaning of the jaranan Turonggo Yakso dance movement. The performance concept is used as a research analysis tool. This research uses descriptive-qualitative methods. The data technique uses observation, interviews, literature study and documentation. The analysis was carried out with in-depth descriptions. The results showed a shift in function from sacred to profane. The form of presentation consists of standard motion and additional motion. This performance movement has a meaning related to farming activities. The image of a jaranan (turonggo) with a giant head (yakso) is a symbol of lust that must be tamed or ridden so that it is not to run wild. 139. 


\section{Pendahuluan}

Keberadaan suatu produk budaya masyarakat sangat berkaitan erat dengan sistem budaya dan sistem sosial masyarakat pemiliknya (Andalas, 2018b). Sebagai representasi identitas kultural, produk budaya suatu masyarakat dapat menjadi alat bagi pemahaman masyarakat pemilik kebudayaan (Andalas, 2018a). Jaranan Turonggo Yakso merupakan salah satu kesenian milik masyarakat Dhongko Kabupaten Trenggalek. Secara historis, kesenian ini lahir dari tradisi ritual yang ada di wilayah ini. Dalam berbagai penyelenggaraan kegiatan, dengan bentuk penyajianya yang khas dan unik, pertunjukan ini masih banyak diminati dan dinikmati oleh para penonton. Tidak heran jika jaranan Turonggo Yakso dapat bertahan di lingkungan masyarakat pendukungnya sampai sekarang. Sebagai salah satu bentuk seni pertunjukan tradisi yang berakar kuat dari kesenian rakyat, pertunjukan jaranan Turonggo Yakso sering dipentaskan pada berbagai kegiatan di dalam lingkungan masyarakat pedesaan dengan latar belakang budaya pertanian atau agraris. Pertunjukan jaranan Turonggo Yakso termasuk dalam kelompok "kesenian lapangan", artinya di dalam penyajiannya sering dilakukan di area lapangan atau halaman luas dikelilingi para penonton. Dahulu pementasan jaranan sering dilakukan bersamaan dengan adanya upacara adat yang disebut baritan. Ketika upacara adat sebagai kegiatan sosial-budaya sudah jarang dilaksanakan, diikuti perkembangan media sosial yang semakin pesat pula, maka kegiatan ritual tersebut kini kurang dikenal bahkan perlahan hilang dari masyarakatnya.

Jaranan Turonggo Yakso saat ini sering dipentaskan secara terpisah menjadi pertunjukan tari jaranan. Menurut Rusianingsih (2017), awal mula jaranan Turonggo Yakso tidak lepas dari upacara baritan sebagai ritual yang dijalankan oleh masyarakat setempat. Pertunjukan kesenian jaranan Turonggo Yakso dalam upacara baritan merupakan satu rangkaian kegiatan yang tidak dapat dipisahkan. Namun, karena upacara baritan saat ini sudah tidak dilaksanakan lagi, maka jaranan Turonggo Yakso pun berdiri sendiri sebagai wujud karya seni pertunjukan.

Ketika pertunjukan jaranan Turonggo Yakso mengalami transformasi fungsi yang dahulunya sebagai "sarana ritual" sekarang berubah menjadi "sarana hiburan", pada akhirnya dapat pula membawa perubahan pada bentuk penyajian maupun makna gerak dalam tariannya. Hal tersebut menjadi fenomena pertunjukan yang menarik untuk diteliti.

Implementasi jaranan terhadap masyarakat pendukung diharapkan tidak hanya sekadar menjadi pementasan tarian saja tanpa memahami tentang bentuk penyajian dan makna geraknya. Karena hal ini banyak "nilai estetik" yang tidak tersampaikan lewat pesan-pesan tata artistik di atas pentas pertunjukan tari jaranan. Dalam berbagai pementasan, tata artistik atau scenography, memiliki peranan di dalam menghadirkan "nilai estetik".Hal tersebut sebagai salah makna penting yang dimiliki oleh tanda-tanda atau simbol yang disajikan melalui bentuk visual di atas panggung (stage) pertunjukan (Purnomo, 2018). Penulis terdorong untuk mengkaji lebih mendalam tentang bentuk penyajian maupun makna gerak di dalam tari jaranan Turonggo Yakso melalui berbagai pertimbangan, yaitu pertunjukan kesenian jaranan Turonggo Yakso sekarang telah mengalami transformasi fungsi dan penelitian tentang bentuk penyajian dan makna gerak di dalam sebuah tarian masih jarang dilakukan secara bersamaan, khususnya terhadap pertunjukan tari jaranan Turonggo Yakso.

Berdasarkan penjelasan dalam latar belakang permasalahan, penelitian dapat difokuskan sebagai berikut: (1) apakah fungsi utama yang menginspirasi terciptanya pertunjukan jaranan Turonggo Yakso kecamatan Dhongko kabupaten Trenggalek?; (2) bagaimanakah bentuk penyajian jaranan Turonggo Yakso kecamatan Dhongko kabupaten Trenggalek? dan (3) apa makna 
gerak tari jaranan Turonggo Yakso kecamatan Dhongko kabupaten Trenggalek?

Kesenian jaranan Turonggo Yakso seharusnya dapat diberdayakan tidak hanya sebagai karya seni pertunjukan semata, namun bisa menjadi karya seni budaya yang berakar kuat pada masyarakat Trenggalek. Hal tersebut dapat dicapai dengan mengembangkan "bentuk penyajian" maupun "makna gerak" tarinya secara kreatif sehingga karakter budaya dan aspek sosialekonomi masyarakatnya dapat terangkat melalui kegiatan pertunjukan.

Pertunjukan adalah sebuah kata yang singkat, namun kompleks dalam makna maupun persoalannya, artinya kegiatan pertunjukan tidak sekadar mementaskan sebuah karya seni lantas selesai. Namun, dalam implementasinya pertunjukan adalah menghadirkan sebuah urutan "laku" (aksi) seseorang atau komunitas. Pertunjukan dilaksanakan di atas panggung untuk bisa menarik banyak perhatian, mampu memberikan hiburan maupun suatu pencerahan sehingga dibutuhkan banyak keterlibatan orang lain yang dalam hal ini adalah para penonton (Yudiaryani, 2002). Implementasi dari pementasan adalah interaksi penonton dengan pemain atau penari melalui karya seni pertunjukan yang dipentaskan. Menurut Purnomo (2015), untuk mewujudkan terselenggaranya sebuah pertunjukan di atas panggung (stage), diperlukan adanya dukungan berbagai unsur pokok yang terdapat di dalam seni pertunjukan, seperti karya, pemain, maupun para penonton. Karena pertunjukan adalah sebuah kegiatan yang mempertemukan antara karya, pemain, maupun para penonton (audience) yang didukung dengan tata panggung (sceno-grafhy) sebagai tempat berekspresi dan berinteraksi (Purnomo, 2015).

Konsep bentuk penyajian berkaitan erat dengan pengertian kata "bentuk" maupun "penyajian" itu sendiri. Bahkan di dalam konteks pemahaman tertentu, bentuk juga diartikan sebagai "pola yang melekat" pada suatu benda. Hal tersebut mengacu pada keterulangan teknik, bangun atau bidang, pengolahan berbagai bahan, bahkan pada bentuk yang paling umum dan konkrit yang diketahui oleh banyak orang (Kattsoff, 2004). Berdasarkan data pengetahuan (empiris), rumusan definisi ini lebih banyak mengacu pada istilah "pola fisik" yang sering kali dipertentangkan dengan "isi" sebagai sebuah bentuk yang lebih abstrak, yaitu kesatuan unsur yang secara sengaja ditata dan diolah lewat keterampilan teknik, sehingga dapat mencapai sebuah ungkapan yang diinginkan. Penyajian dapat diartikan sebagai cara menyampaikan atau menghidangkan wujud tersebut agar dapat dinikmati oleh penonton. Jadi "bentuk penyajian" adalah apa yang disajikan (dipertunjukan) dari kesenian tersebut atau wujud sebuah penyajian yang secara keseluruhan mencakup berbagai aspek pendukung, yaitu tema tari, tata gerak, tata iringan, tata pentas, tata rias-busana, properti yang secara komprehensif terintegrasi pula menjadi satu kesatuan yang saling berkaitan (Soedarsono, 2002). Menurut Hadi (2007), aspek bentuk sangat berhubungan dengan teknik maupun konteks isinya. Selain itu "bentuk penyajian" juga mengupas mengenai elemen dasar sebuah koreografi, seperti halnya desain dramatik, desain lantai, desain atas, desain musik, gerak ruang dan waktu.

Bentuk penyajian sebuah pementasan karya seni pertunjukan (tari) senantiasa mempunyai makna simbolis, baik lewat segi gerak tari, tata rias, tata busana, iringan/musik, perlengkapan dan properti. Istilah penyajian adalah hadirnya simbolsimbol atau tanda di dalam suatu pementasan (Smith, 1985). Makna di dalam penelitian mengenai seni pertunjukan dapat dianalisis secara simbolik dengan perspektif hermenuetik. Analisis seni secara simbolik dengan secara hermenuetik, semestinya terlebih duhulu perlu memperhatikan pandangan-pandangan sang seniman atau masyarakat pendukung dari karya seni itu. Hal tersebut dilakukan sebelum menafsirkan atau menginterpretasikan fenomena atau pertunjukan seni (Hadi, 2007). Menurut Smith (1985), simbol berasal dari istilah Yunani symbolos berarti tanda yang dapat 
memberikan sesuatu makna kepada orang lain. Dengan demikian simbol adalah bentuk lahiriah yang mengandung adanya maksud, sedangkan makna merupakan isinya.

Makna simbolis masyarakat tradisional biasanya penuh dengan supranaturalisme yang sangat erat dan sulit untuk dilepas-kan begitu saja tanpa adanya alasan yang jelas. Ciri-ciri tentang makna kerakyatan tradisional lebih cenderung (condong) pada ciri kehambaan terhadap kekuasaan. Hal tersebut dinyatakan dalam bentuk simbol yang dapat mengikat perilaku masyarakatnya (Herusatoto, 1983). Menurut Langer (2006), simbol tersebut tidak mewakili objeknya, tetapi dapat menjadi wahana bagi konsep tentang objek. Lebih jauh Langer juga membedakan antara simbol diskursif dan simbol presentatif. Simbol diskrusif digunakan dalam bahasa tulis dan lisan untuk keperluan komunikasi dengan pihak lain. Simbol ini berupa penjelasan sesuatu yang dikomunikasikan berdasarkan pada nalar atau pikiran. Simbol presentatif, misalnya gambar, merupakan bahasa presentasi suatu makna yang tak terkatakan di dalam simbol diskursif. Simbol presentatif adalah simbol yang dikomunikasikan berdasarkan instuisi langsung ataupun perasaan (simbol-seni). Kesimpulannya, bahwa jika sebuah simbol diungkapkan, maka muncullah "makna". Teori makna digunakan untuk memberikan pengetahuan lebih mendalam sehingga bisa membantu meng-indentifikasi makna dari gerak tari (Langer, 2006).

Konsep gerak merupakan unsur yang paling besar peranannya di dalam seni tari. Dengan bergerak, maka dapat diketahui terjadinya perubahan tempat, perubahan posisi dari benda, tubuh penari, waktu atau berbagai gerak tubuh. Unsur pokok dalam tari, ruang dan gerak adalah sebuah media untuk mengungkapkan ekspresi tari. Ruang merupakan unsur penunjang yang dapat digunakan sebagai penjelajahan gerak.

Penguasaan ruang merupakan faktor penting sebagai proses penggarapan suatu tarian, sedangkan waktu erat hubungannya dengan ritme. Ritme merupakan media yang mengatur dinamika dalam sebuah
tarian.Keselarasan dari ketiga unsur pokok tersebut dikatakan sebagai harmoni yang merupakan keseimbangan sebagai satu kesatuan yang diungkapkan dalam suatu tarian. Berdasarkan pada bentuknya, gerak tari dapat dibedakan menjadi dua, yaitu tari represetasional dan non-representasional. Tari representasional adalah tari yang menggambarkan sesuatu dengan jelas (wantah), sedangkan tari nonrepresentasional adalah tari yang menggambarkan sesuatu secara simbolis, biasanya memakai gerak (maknawi).

Tujuan yang ingin dicapai di dalam penelitian ini adalah mendeskripsikan fungsi utama yang menjadi inspirasi lahir-nya pertunjukan jaranan Turonggo Yakso kecamatan Dhongko kabupaten Trenggalek, menjelaskan bentuk penyajian jaranan Turonggo Yakso kecamatan Dhongko kabupaten Trenggalek, dan mendeskripsikan makna gerak tari jaranan Turonggo Yakso kecamatan Dongko Kabupaten Trenggalek. Penelitian ini diharapkan memberikan sumbangan keilmuan secara umum, perkembangan keilmuan seni, dan berbagai bidang terkait. Diharapkan juga menjadi inspirasi motivasi terhadap perkembangan seni pertunjukan, dan seni tari khususnya. Kedua dapat memberikan sumbangan pemikiran para praktisi dan akademisi di bidang seni pertunjukan.

\section{Metode}

Fenomena terjadi ketika kegiatan upacara baritan tidak dilaksanakan lagi, sehingga mengakibatkan kesenian jaranan Turonggo Yakso mengalami transformasi fungsi sebagai hiburan. Hal tersebut akhirnya membawa perubahan pula terhadap pertunjukan, sehingga untuk memahami fenomena yang terjadi maka pendekatan atau strategi penelitian dilakukan lewat bentuk penyajian dan makna gerak tari jaranan Turonggo Yakso.

Subjek penelitian ini adalah kesenian jaranan Turonggo Yakso, dan orang-orang yang terlibat sebagai informan: pimpinan sanggar, pemain, penggambuh, praktisi seni yang aktif dalam pertunjukan kesenian 
jaranan Turonggo Yakso. Objek penelitian ini adalah bentuk penyajian dan makna gerak tari jaranan Turonggo Yakso kecamatan Dhongko Kabupaten Trenggalek.

Teknik pengumpulan data yang digunakan, yaitu (1) observasi partisipan terhadap penari, pawang, pimpinan jaranan dan tokoh masyarakat yang terlibat dalam pertunjukan, serta berkaitan erat di dalam penelitian. Observasi penelitian memakai teknik non participan observation, yakni peneliti datang menuju tempat kegiatan pertunjukan jaranan Turonggo Yakso Dhongko Trenggalek namun tidak terlibat secara langsung dalam kegiatan kesenian. Observasi dilakukan agar dapat mengamati secara langsung bentuk penyajian jaranan Turonggo Yakso beserta elemen-elemen pendukungnya. Observasi yang dilakukan bersifat deskriptif (Spradley, 2006). 2) Wawancara dilakukan pada informan kunci (Bungin, 2012), yaitu pimpinan jaranan, tokoh masyarakat, dan penari. 3) Studi pustaka untuk mendapatkan data-data referensi yang berhubungan dengan keberadaan kesenian jaranan, dan dokumen untuk mendapatkan data-data melalui rekaman audio-visual pertunjukan jaranan Turonggo Yakso..

Analisis data dilakukan dengan deskripsi mendalam, yaitu dengan mengategorikan data sesuai rumusan masalah dan mencari pola-pola yang muncul pada data. Pola-pola ini kemudian dimaknai (Emzir, 2012). Untuk mengukur validitas data penelitian dilakukan dengan triangulasi dengan mengkaitkan dengan metode pengumpulan dan analisis data sekaligus, termasuk menggunakan para informan sebagai alat uji keabsahan dan analisis hasil penelitian. Proses triangulasi sebagai validitas data penelitian dijalankan secara berkelanjutan selama kegiatan proses pengumpulan berbagai data atau kegiatan dalam analisis data.

\section{Hasil dan Pembahasan}

Jaranan Turonggo Yakso berkembang di daerah Trenggalek sebagai wilayah yang berad a di pesisir Selatan pulau Jawa. Jaranan ini merupakan kesenian rakyat berasal dari kecamatan Dhongko, sebuah wilayah yang terletak di pegunungan ke arah Selatan kota Trenggalek. Masyarakat Dhongko dahulu mengadakan upacara adat baritan yang tumbuh turun temurun. Sehingga upacara bersih desa itu dapat berkembang menjadi bagian kehidupan masyarakat yang ada di wilayah tersebut.

Berawal dari upacara adat baritan yang diselenggarakan masyarakat daerah Dhongko inilah kesenian jaranan Turonggo Yakso diciptakan. Dahulu kegiatan upacara tersebut dilaksanakan secara rutin dan turun temurun sesuai dengan ketetapan waktu yang ditentukan oleh orang tua sebagai pemimpin yang mengetahui dan menguasai ritual - adat.

Kehadiran jaranan Turonggo Yakso yang berawal dari upacara adat biasanya berkaitan erat dengan suatu tindakan yang diyakini. Ritual atau upacara keagamaan merupakan salah satu perangkat tindakan nyata, sebagai cara membuat adat kebiasaan atau kegiatan beragama sesuai dengan "sesuatu" yang diyakini. Ritual dilaksanakan berdasarkan pada agama atau tradisi komunitas tertentu, baik untuk kepentingan pribadi ataupun kelompok. Hal ini dapat membentuk disposisi atau kecenderungan perilaku pribadi dari pelaku ritual sesuai dengan adat dan budaya masing-masing.

Setiap kegiatan upacara atau ritual dipengaruhi berbagai faktor yang sangat diyakini oleh masyarakat penganutnya. Hal tersebut seperti disampaikan oleh (Koentjaraningrat, 2009), bahwa di dalam setiap kegiatan ritual atau upacara keagamaan yang diselenggarakan terdapat empat faktor yang senantiasa melekat, yaitu 1) tempat dimana upacara keagamaan tersebut dilakukan, 2) waktu dimana upacara tersebut dijalankan, 3) sarana atau peralatan upacara yang digunakan dan 4) pelaku yang menyelenggarakan atau memimpin jalannya kegiatan upacara. Berikutnya (Koentjaraningrat, 1992) juga mengatakan, kegiatan upacara atau ritual yang diselenggarakan dan dihadiri oleh masyarakatnya, berarti berpeluang juga memancing dan membangkitkan "emosi" keagamaan setiap kelompok masyarakat 
penganutnya, maupun setiap individu yang menghadiri kegiatan tersebut. Hal itu juga didasarkan pada upacara adat yang diselenggarakan, dan merupakan bagian dari kegiatan yang dapat mengungkapkan emosi keagamaan mereka. Hal ini karena masyarakat pendukungnya sudah menjadi penganut cukup lama. Seni pertunjukan akan selalu terikat dengan konteks tempat kebudayaan tersebut tumbuh dan berelasi kuat dengan kedudukannya dalam struktur budaya masyarakat pemiliknya (Andalas, 2016).

Baritan adalah upacara adat bersih desa yang bertujuan memohon kepada Hyang Widi agar rojo koyo (hewan ternak) mereka dapat terhindar dari segala penyakit. Selain itu juga menjadi simbolisasi perjuangan masyarakat dalam mengusir keangkaramurkaan yang mengganggu desanya. Hal yang paling penting dan perlu dipahami bahwa ritual baritan dilaksanakan sesuai dengan kesepakatan mengenai tempat, waktu, sarana, dan pelaku yang terlibat kegiatan upacara tersebut.

Dalam penyelenggaraan pertunjukan jaranan Turonggo Yakso saat ini sangat bergantung pada perkembangan kondisi masyarakat yang terdampak situasi pandemi Covid-19. Berbagai komunitas jaranan, Turonggo Yakso khususnya, sering kondisi masyarakat yang tidak menentu posisi sosial dan ekonominya, sehingga hal tersebut sangat mempengaruhi terhadap kegiatan yang berkaitan secara langsung dengan penyelenggaraan pertunjukan.

\subsection{Fungsi Pertunjukan Jaranan Turonggo Yakso}

Mata pencaharian masyarakat Dhongko yang sehari-hari bekerja sebagai petani dan pedagangmenjadikan kegiatan upacara atau ritual adat menjadi bagian penting kehidupan nya. Pertunjukan menjadi sarana atau media komunikasi dalam masyarakat. Dalam implementasinya, setelah melaksanakan upacara bersih desa, akan diteruskan dengan pementasan kesenian tayub di tempat diadakannya ritual tersebut. Sedangkan anyaman tali besar yang biasanya disebut dengan dhadhung, yang menjadi bagian dari sesaji yang telah dimanterai, akan dibagibagikan kepada para pemiliknya. Karena menurut kepercayaan mereka, dengan menyimpan tali dhadhung yang telah dimanterai hewan-hewan warga akan terhindar dari gangguan marabahaya dan wabah penyakit.

Kegiatan ritual atau upacara adat baritan sekarang sudah mulai ditinggalkan oleh masyarakat pendukungnya, sehingga untuk melestarikan dan merefleksikan kembali ritual baritan, akhirnya lahirlah ide menciptakan bentuk karya seni yang dapat mendatangkan warga masyarakat secara luas. Wilayah Dongko Kabupaten Trenggalek, yang dikenal mayoritas berbudaya agraris, banyak memberi peluang hadirnya karya seni pertunjukan yang berkiblat pada kulturbudaya masyarakatnya. Hal ini seperti yang dijelaskan Pak Pamrih (pencipta Turonggo Yakso), bahwa untuk menciptakan gerakan tari jaranan beliau harus memahami baritan sebagai kegiatan masyarakat daerah Dhongko yang berlatar belakang sebagai seorang petani. Hal ini karena dalam implementasi sebuah pertunjukan diperlukan adanya interaksi antara penonton dengan pemain atau penari melalui karya seni yang dipentaskan. Untuk lebih jelasnya dapat dilihat pada Gambar 1 berikut.

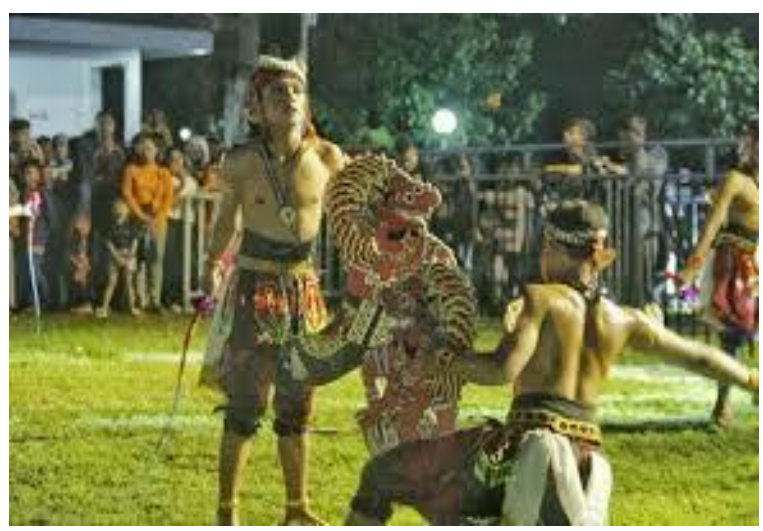

Gambar 1 Pertunjukan jaranan Turonggo Yakso di lapangan yang disaksikan oleh para penonton secara langsung (live) (Sumber: Tatang, 2019).

Setelah semua rangkaian kegiatan ritual baritan selesai, maka ditampilkan 
kesenian jaranan Turonggo Yakso yang koreografi awalnya diciptakan Pak Pamrih pada tahun 1979-an. Dalam hal ini, untuk dapat memproyeksikan kembali nilai estetik kesenian jaranan, maka ide penciptaan tidak hanya pada bentuk tariannya saja, namun musik pengiringnya juga berperan sangat penting untuk dihadirkan. Sebagai hasilnya terjadi perpaduan antara gerak tari dengan musik pengiring yang harmonis menjadi karakter penting dalam penyajian kesenian jaranan Turonggo Yakso.

Saat ini, fungsi pertunjukan jaranan Turonggo Yakso secara langsung sudah tidak berkaitan dengan kegiatan ritual baritan. Meskipun pada awal mulanya kesenian jaranan Turonggo Yakso bermula dari daerah Dhongko, namun perkembangan di luar daerah juga sangat pesat. Pertunjukan jaranan sering diselenggarakan di berbagai daerah untuk mengisi kegiatan atau berbagai acara "hiburan". Bahkan, setiap tahun di Kabupaten Trenggalek senantiasa diadakan festival dan pementasan jaranan secara rutin. Karena hal ini, pertunjukan jaranan Turonggo Yakso telah mengalami transformasi fungsi yang dahulu sebagai sarana ritual kini berubah menjadi sarana hiburan yang akhirnya dapat pula membawa perubahan bentuk penyajian maupun makna gerak dalam tariannya.

\subsection{Bentuk Penyajian Jaranan Turonggo Yakso}

Sampai sekarang, pertunjukan jaranan Turonggo Yakso memiliki bentuk penyajian yang tidak terikat, artinya terdapat adanya kebebasan di dalam pola koreografinya yang lebih bersifat atraktif. Bentuk penyajiann merupakan wujud visual kesenian jaranan sebagai karya seni yang disatukan lewat komposisi tari, tata gerak, tata iringan, tata pentas, tata rias, tata busana, properti dan sebagainya. Untuk lebih jelasnya dapat dilihat pada visual Gambar 2 di bawah ini.

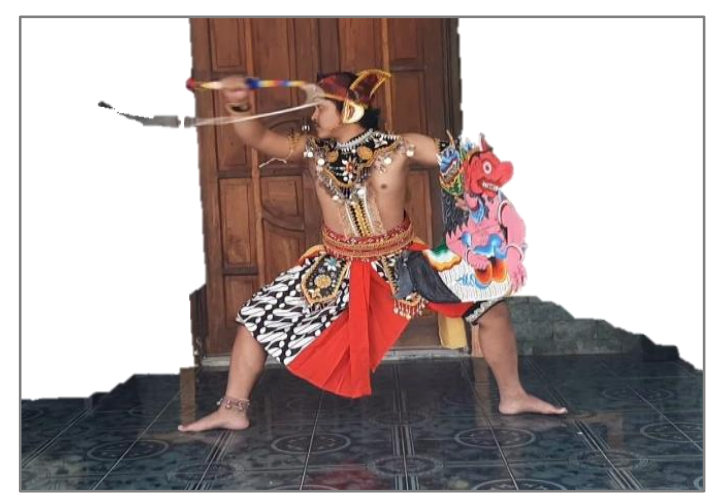

Gambar 2 Visual tari jaranan Turonggo Yakso yang diperagakan penari sanggar Purwo Budoyo Dhongko Trenggalek (dok. Peneliti, 2020)

Kesenian jaranan tersebut dapat tampil sebagai sebuah pertunjukan yang dinikmati secara utuh di atas pentas oleh para penonton. Menurut Purnomo \& Subari (2019), kejayaan suatu pertunjukan dapat ditentukan dari kehadiran para penonton (audience). Ketika penonton mulai sepi, maka kegiatan pertunjukan tersebut juga semakin memudar keberadaannya. Berbagai faktor sosial dan ekonomi dalam masyarakat, pada waktu sekarang dapat menjadikan pertunjukan karya seni tradisi sepi penonton. Akhirnya hal tersebut dapat menjadi pemicu persoalan yang berkaitan pementasan yang lainnya.

Dalam implementasinya di masyarakat, bentuk penyajian jaranan Turonggo Yakso mengalami perkembangan yang dapat dipilahkan menjadi sebagai berikut. Pertama, asalusul jaranan Turonggo Yakso, yaitu berawal kepedulian seseorang bernama Teguh untuk mempertahankan supaya ritual baritan beserta keseniannya tidak punah begitu saja. Maka beliau mencari seorang yang mampu menciptakan bentuk kesenian yang dapat dimasukkan (kolaborasi) dengan kegiatan baritan. Lewat saudara tuanya, Pak Pamrih yang berasal dari daerah Tulungagung diciptakanlah tari jaranan bersumber dari gerakan para petani Dhongko. Gerakan raksasa (buto) dihadirkan untuk menambah kekuatan tarian sekaligus dimunculkan dalam propertinya. Sedangkan bentuk 
penyajian jaranan Turonggo Yakso telah menyatu dalam kegiatan ritual maupun sebagai hiburan dalam masyarakatnya.

Kedua, keberadaan jaranan Turonggo Yakso, yaitu ketika masyarakat Dhongko sudah tidak mengadakan lagi kegiatan upacara adat baritan sampai sekarang. Bentuk penyajian jaranan Turonggo Yakso kini menyatu dalam berbagai kegiatan festival ataupun hiburan yang diselenggarakan oleh masyarakat pendukungnya.

\subsection{Makna Gerak Tari Jaranan Turonggo Yakso}

Implementasi gerak tari di dalam penyajian jaranan Turonggo Yakso juga tidak memiliki aturan yang baku. Hal tersebut dilakukan supaya bentuk penyajian maupun karakteristik tarinya yang dinamis energik dan atraktif dapat dipertahankan. Kegiatan festival dan pementasan kesenian jaranan Turonggo Yakso di Kabupaten Trenggalek diselenggarakan secara rutin setiap tahunnya sehingga sering bermunculan ragam gerak dan teknik baru pada waktu pementasan.

Ketika jaranan Turonggo Yakso pada awal-mula diciptakan Pak Pamrih, tarian ini memiliki dua ragam gerak pokok yang selalu bisa dikembangkan, yaitu ukel atau gerak baku, yaitu merupakan ragam sebagai ciri khas gerakan kesenian jaranan Turonggo Yakso dan lawung atau gerak tambahan, yaitu gerak tambahan yang tidak bisa dipisahkan ketika terjadi peralihan dari gerak baku (ukel) yang satu ke ukel lainnya. Ragam gerak yang diciptakan dengan latar belakang masyarakat Dhongko, yang mayoritas petani, di dalam pertunjukan dibagi menjadi beberapa gerak ukel. Masing-masing ukel memiliki makna ataupun arti yang berbeda, dan beberapa gerak tambahan atau lawung digunakan sebagai gerak penghubung diantara gerakgerak ukel lainnya. Berikut rincian gerakan ukel dan lawung pada tari jaranan Turonggo Yakso.

\section{Gerak Baku (Ukel)}

(1) Budalan: ragam gerak ini diambil dari gerakan bapak dan ibu petani yang berangkat kerja ke sawah.

(2) Sembahan: ragam ini menggambarkan gerak nenuwun, yaitu sikap meminta keselamatan kepada Tuhan Yang Maha Esa.

(3) Negar sengkrak:ragam gerak ini diambil dari gerakan petani yang mengelilingi sawah atau berjalan di pematang.

(4) Sengkrak gejuk:ragam gerak ini menggambarkan petani waktu mencangkul sawah.

(5) Sirik gejuk: gerakan yang menggambar kan petani waktu menanam padi (tandur).

(6) Gagak lincak:ragam gerak yang meng-gambarkan gerakan petani waktu membersihkan rumput (matun).

(7) Lompat gantung: menggambarkan gerakan petani waktu memupuk tanaman padi.

(8) Lompat gejuk: ragam yang menggambarkan gerakan petani waktu menuai padi (panen).

(9) Makan minum: ragam yang menggambarkan gerakan petani waktu kegiatan makan dan minum.

(10) Perang-perangan atau bersenangsenang/ gegojekan: menggambarkan gerakan petaniwaktu bergembira ketika sedang panen, ragam ini dibagi lagi menjadi gerak: (a) sikut-sikutan dan (b) tiban.

(11)Pulang, ulih - ulihan: gerakan yang menggambarkan petani selesai bekerja dari sawah (pulang).

\section{Gerak Tambahan (Lawung)}

(1) Lawung lumaksono: gerakan berjalan biasa yang diatur sedemikian rupa dengan gerakan melangkah ke depan secara bergantian.

(2) Lawung lampah tigo: gerakan berjalan biasa yang diatur sedemikian rupa 
dengan gerakan melangkah ke depan dan ke belakang.

(3) Lawung ngigel: gerakan sambil jalan dengan menggerakkan bahu badan.

(4) Lawung nggareng: gerakan berjalan dengan langkah kaki seperti wayang gareng.

(5) Lawung reting: gerakan jalan dengan gerak kaki ke kanan dan ke kiri bergantian.

(6) Lawung tolehan: gerakan berjalan kaki kiri dan kanan menyamping sedemikian rupa dengan diikuti gerak kepala menoleh ke kanan dan ke kiri.

Gerakan-gerakan (ragam gerak) pada tari jaranan Turonggo Yakso yang diciptakan oleh Pak Pamrih sangat sederhana dan tegas. Seperti tampak pada Gambar 3 berikut.

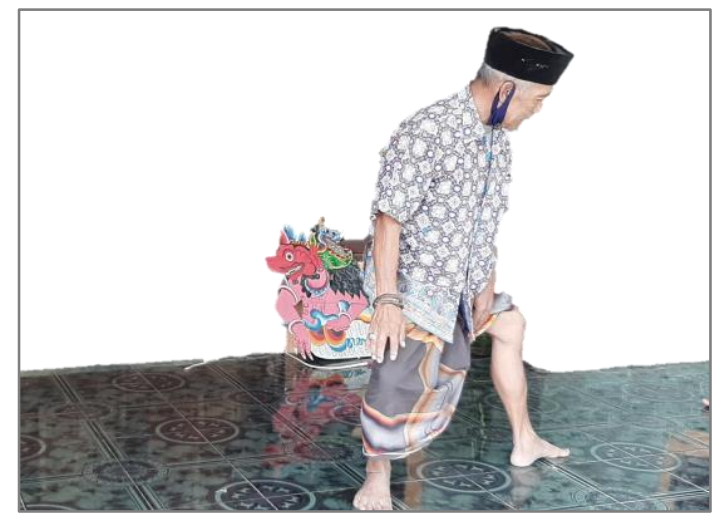

Gambar 3 Rekonstruksi sikap kuda - kuda pada jaranan Turonggo Yakso yang diperagakan secara langsung oleh Pak Pamrih (dok. Peneliti, 2020)

Setiap gerakan tidak memiliki arti ataupun makna yang khusus, apalagi memiliki arti filosofis tertentu. Setiap gerakan senantiasa memvisualisasikan aktivitas petani yang bekerja, sehingga susunan gerak tari jaranan Turonggo Yakso apabila diperhatikan dan dicermati, merupakan aktivitas para petani berangkat ke sawah. Hal ini ditunjukkan melalui ragam: ukel budalan-ukel sirik gejuk-ukel ulih ulihan. Jika gerakan dalam jaranan Turonggo Yakso adalah simbol, maka hal tersebut tidak mewakili objek (petani), namun simbol bisa dijadikan sarana untuk memvisualkan objek.

\section{Kesimpulan}

Untuk membaca bentuk penyajian dan makna gerak tari jaranan Turonggo Yakso perlu dilakukan secana komprehensif lewat visual diatas stage. Bentuk maupun makna sering muncul lewat pertunjukan yang secara total. Dalam pementasan jaranan Turonggo Yakso bisa-jadi bentuk dan makna hadir melalui properti yang dinaiki penari, yaitu jaranan (turonggo)yang berkepala raksasa (yakso). Visual properti merupakan simbol dari hawa nafsu yang harus dijinakkan atau ditunggangi agar tidak liar. Pada prinsipnya pertunjukan adalah muara atau bertemunya interaksi antara penari dengan penonton. Penonton harus mencari sendiri tentang bentuk penyajian dan makna gerak, melalui interpretasi (tafsir) masing-masing.

Situasi pandemi Covid-19 yang sekarang memasuki era tatanan newnormal, dapat mempengaruhi setiap kegiatan komunitas kesenian yang sering mengandalkan keterkaitan dengan masyarakat pendukungnya. Kini pementasan yang setiap kali diselenggarakan secara langsug (live) juga sudah semakin susah dijumpai. Keberadaan komunitas kesenian jaranan yang bersifat komunal dan lapangan, kini pun menghadapi kerasnya persaingan dengan situasi yang kurang menguntungkan. Kebutuhan akan data penelitian banyak mengalami kendala dan ketergantungan dengan situasi lapangan ataupun lingkungan.

\section{Daftar Pustaka}

Andalas, E. F. (2016). Sastra Lisan Lakon Lahire Panji dalam Pertunjukan Wayang Topeng Malangan Padepokan Mangun Dharma: Kajian Sastra Lisan Ruth H Finnegan. Universitas Airlangga.

Andalas, E. F. (2018a). Cerita Rakyat dan Tradisi Masyarakat Agraris Nusantara: 
Mitos Dewi Sri (Jawa) dan Legenda Putri Mandalika (Sasak). In P. Karyanto (Ed.), Kisah-Kisah Perempuan dan Cerita Rakyat Nusantara (pp. 1-12). Kajian Sastra dan Budaya Universitas Airlangga.

Andalas, E. F. (2018b). Meninjau Kembali Identitas Jawa: Panji Sebuah Representasi Identitas Lokal Jawa Timur. Budaya Jawa Dalam Tantangan Globalisasi Dan Pengembangan Budaya Nasional. researchgate.net

Bungin, B. (2012). Analisis Data Penelitian Kualitatif, Kualitatif Filosofis dan Metodelogis ke Arah Penguasaan Model Aplikasi. Rajawali Press.

Emzir. (2012). Analisis Data: Metodologi Penelitian Kualitatif. Rajawali Press.

Hadi, Y. S. (2007). Kajian Tari Teks dan Konteks. Pustaka Book Publisher.

Herusatoto, B. (1983). Simbolisme di Dalam Budaya Jawa. Hanindita.

Kattsoff, L. O. (2004). Pengantar Filsafat. Tiara Wacana.

Koentjaraningrat. (1992). Beberapa Pokok Antropologi Sosial. Dian Rakyat.

Koentjaraningrat. (2009). Pengantar Ilmu Antropologi. Rineka Cipta.

Langer, S. K. (2006). Problem Of Art Ten Philosophical Lectures. Asti.

Purnomo, H. (2015). Aneka Ria Srimulat: Kajian Seni Populer di Kompleks Taman Hiburan Rakyat Surabaya.

Purnomo, H. (2018). Tata Artistik (Scenografi) dalam Pertunjukan Kesenian Tradisi Berbasis Kerakyatan. JURNAL SATWIKA, 2(2), 95-106. https://doi.org/https://doi.org/10.22219/ SATWIKA.Vol2.No2.95-106

Purnomo, H., \& Subari, L. (2019).
Manajemen Produksi Pergelaran: Peranan Leadership dalam Komunitas Seni Pertunjukan. JURNAL SATWIKA, $3(2)$, 111-124. https://d oi.org/https://doi.org/10.22219/ SATWIKA.Vol3.No2.111-124

Rusianingsih, T. (2017). Fungsi dan Makna Simbolis Kesenian Jaranan Turonggo Yakso Kecamatan Dhongko Kabupaten Trenggalek. Jurnal Terop, 6(1), 90101.

Smith, J. (1985). Komposisi Tari sebuah Petunjuk Praktis Bagi Guru. Ikalasti.

Soedarsono. (2002). Seni Pertunjukan Di Era Globalisasi. Gajah Mada University Press.

Spradley, J. (2006). Metode Etnografi. Tiara Wacana.

Yudiaryani. (2002). Panggung Teater Dunia: Perkembangan dan Perubahan Konvensi. Pustaka Gondho Suli.

Tatang. 2019. Seniman Trenggalek Kolabo rasi Jaranan TuronggoYakso dengan Musik Jazz (https://m.suarajatimpost.com/read/ 2460/20191209/192054/senimantrengg alek-kolaborasikan-jarananturonggoyakso-de ngan-musik-jazz diakses 01 Agustus 2020). 